\title{
Benchmarking in TESOL: A Study of the Malaysia Education Blueprint 2013
}

\author{
Arif Jawaid $^{1}$ \\ ${ }^{1}$ Centre for Modern Languages \& Communication, Linton University College, Malaysia \\ Correspondence: Arif Jawaid, Director, Centre for Modern Languages \& Communication, Linton University \\ College, Malaysia. Telephone: 60-169-041-250. E-mail: arifjawaid54@yahoo.com
}

Received: February 25, 2014 Accepted: June 27, 2014 Online Published: July 15, 2014

doi:10.5539/elt.v7n8p23 URL: http://dx.doi.org/10.5539/elt.v7n8p23

\begin{abstract}
Benchmarking is a very common real-life function occurring every moment unnoticed. It has travelled from industry to education like other quality disciplines. Initially benchmarking was used in higher education. .Now it is diffusing into other areas including TESOL (Teaching English to Speakers of Other Languages), which has yet to devise a comprehensive framework of assessment of a given TESOL provision, for instance that of Malaysia Education Blueprint 2013. This paper is derived from the author's research into improvement of TESOL, Curriculum in Lahore, Pakistan, based upon a comparative analysis of TESOL in Birmingham, United Kingdom. In the research, many benchmarks were drawn from a detailed comparative analysis and synthesis of extant literature, leading to the development and codification of quality characteristics and standards. Eventually, result was "TESOL Quality Audit Framework" that can be a prelude to improving learning and teaching strategies, staff, curriculum and institutional performance. In addition, the high impact benchmarks were used to formulate TESOL curriculum fit-for Malaysian preschool children (4-7 year olds) and teachers. A detailed worked example based upon four selected benchmarks, emphasizing use of one-day real-life project is illustrated. These projects have been utilized successfully to step-up the learning of both children and their teachers since 2000 . The potential users of this workable framework consist of preschool and primary school children, teachers, TESOL teachers, curriculum policy makers and English curriculum coordinators, trainee preschool and primary school teachers, ministries and the departments dealing with pre-schoolers and younger children.
\end{abstract}

Keywords: auditing, benchmarking, curriculum, TESOL quality audit framework

\section{Introduction}

There is a dire need to address the complexity and challenges of second language learning and teaching in Malaysia (Malaysia Education Blue Blueprint, 2013). This is obviously due to lack of a comprehensive TESOL framework which could meet the language and education needs of Potential English Proficient Children (PEPC) and the teachers of Malaysia. Similar concerns were noticed in Pakistan. To address them, a trans-comparative study was carried out using benchmarking process. The outcome of the study was a TESOL framework comprising a range of benchmarks to improve learning and teaching. The initial concern that TESOL provision in Pakistan was inadequate implies a comparison (benchmarking). This is because if something is sub-standard there has to be a standard as well, against which to judge (Jawaid, 1998).

The main objective of the aforementioned comparative study was to develop a curriculum framework that conceptualised and codified TESOL benchmarks in four selected good Birmingham primary schools, UK. For convenience, these benchmarks were codified as Quality Characteristics (QCs) and Quality Standards (QSs) in order to identify the actual situation in the U.K. and Pakistan. This study facilitated to highlight the differences in practice referred as 'quality deficiencies', and thus to formulate an improvement plan for Pakistan. It is worth mentioning, the existing TESOL models were not appropriate for this research because there is no agreement between SLA researchers about SLA model due to diverse requirements of the researchers (Ellis, 1994). Nunan (1988) took the lead to produce one but his model is primarily for adults and does not relate directly to this study which is focused on younger learners (4-7 year olds). Similarly, task-based methodology proposed by Dave and Willis (2007) provides just an outline not a framework.

An empirical study as part of the above research was carried out in four primary schools in Birmingham, U.K. where children from ethnic minorities (Mirpuri, Punjabi) made up the majority of the school population. The 
schools were recommended by Birmingham Local Education Authority as good schools and had $90-95 \%$ Punjabi children. There the children came from homes where the mostly spoken language was their mother tongue (Punjabi, Mirpuri). It was assumed that TESOL provision in UK could provide "good practice" because a lot of national strategies and programmes have been enacted to bring the above children to the level of mainstream students (Jawaid, 2014). A recent Office for Standards in Education (Ofsted) Report (2012) also commended one of these schools stating pupils learning English as an additional language do exceptionally well at Greet Primary School because the outstanding teaching they receive throughout the school is complemented by high-quality support and a language-rich curriculum. As a result, pupils develop highly advanced writing skills. The development of the framework was an iterative process (a process of arriving at a decision by repeating rounds of analyses) of collecting, coding and analyzing good practices found in the literature and fieldwork. The constant comparative analysis process (benchmarking) was a process very much in the grounded theory tradition (Glaser \& Strauss, 1967). For instance, the researchers state that joint collection, coding and analysis of data is the underlying operation. The generation of theory, coupled with the notion of theory as process, requires that all three operations be done together as much as possible (Glaser \& Strauss, 1967).

To commence benchmarking identification process, an in depth literature review was carried out to identify quality characteristics and quality standards that could be verified and/or adjusted and added to as a result of the fieldwork. Initially, observation checklist was used to collect the data, but it was felt that a lot of useful data could not be captured. Hence, to capture maximum benchmarks (good practices), the data was collected using the "Thick Description" approach recommended by Geertz (1973). Each "Thick Description" of a lesson was transcribed and then typed up for the open coding process. The researcher then re-examined the incidents under the coding process and defined them more clearly by relating the incidents to the Quality Standards that had been previously derived from the literature. Interviews with teachers and head teachers (informal and formal) were also carried out to discuss their actions and intentions as well as learning and teaching strategies used.

To validate and enhance the TESOL Quality Audit Framework, in addition to the observations, interviews and discussions, the data was collected through content analysis of school documents such as development plans, language policy, home-school liaison policy, schemes of work, assessment schemes and various related documents including the Ofsted Reports. This content analysis assisted in the process of triangulation-cross-checking and corroborating other data. As the researcher had a respectable concern for the validation of the framework, a routine of triangulation was followed to cross-check the validity of the research data. Consequently, the outcome of this study was TESOL Quality Audit Framework. Four cyclic benchmarks were carefully selected from this framework and applied to improve Malaysian TESOL provision.

\section{Literature Review}

\subsection{Benchmarking Process to Improve TESOL Provision}

The benchmarking used in this research was generic and it involved making comparisons with typically comparative but non-competitive organisations. Moreover, the creation and validation of benchmarks allow comparisons to be made between parts of the same school (year levels and between classes in the same year) and between similar schools. That being so, the benchmarking programme requires a clear strategy and criteria by which to identify good practice (Pike \& Barnes, 1996). The term benchmarking has entered into education through industry (O'Hanlon, 1996). Benchmarking has been defined by many authors such as Bendell, Boulter, and Kelly (1993), Codling (1994), Sallis (1996) and Watson, Modgill, and Modgill (1997). Bendell, Boulter, and Kelly's (1993) definition is general in its approach, for they define benchmarking as:

The process of identifying and learning from best practices anywhere in the world ... in the quest for continuous improvement (Bendell, Boulter, \& Kelly, 1993, p. 208).

Sallis's definition, however, has been utilised because it defines benchmarking in terms of quality characteristics and standards in the context of education. Sallis writes:

"A valuable exercise for an institution is to establish the learner's career-path and to identify against each milestone the quality characteristics and quality standards that should be in place". (Sallis, 1996, p. 101)

Sallis defines benchmarking in terms of quality characteristics and standards in the context of education. This definition suggests that benchmarking is a process of establishing a standard against which to measure present performance of an institution in order to identify and possibly achieve improvement in provision. Benchmarking in this study is defined as:

"A process of comparing TESOL performance of selected school (s) against TESOL good practice derived from literature and research codified in quality characteristics and quality standards. The application of such is 
designed to support the improvement of the English language learning of students whose first language is not English."

\subsection{The Concept of Quality Characteristics and Quality Standards}

Following definition of benchmarking, the research identified and used Quality Characteristics and Quality Standards. According to the definitions of Moreland and Horsburgh (1992) and Dahlgaard, Kristensen, \& Kanji (1994), a Quality Characteristic is an aspect, section or component of provision necessary for the achievement of overall quality acceptable to stakeholders.

Typically, in order for a product or service to be defined as possessing quality, it normally has a number of quality characteristics. In a cafe, for instance, there is a product aspect (e.g. an unchipped, clean and hot cup of tea), a level of delivery aspect (e.g. tea presented without slops in the saucer), and an environment aspect conducive to the service provision and perceptions of quality. Each of these aspects forms a Quality Characteristic, whilst the unchipped cup, clean cup and hot tea are quality standards within a particular quality characteristic. It is also worth explaining the use of interchangeable terms "benchmark"/"good practice"/best practice. With respect to the term "best practice", the researcher preferred to take heed of a statement from Harrington (1997). He cautions that the idea of a universally beneficial set of best practices proved to be unsound. Hence due to the reason of fast changes and variety of TESOL situations, the term, "good practice"/"benchmark" was adopted in this case study. The "good practice"/"benchmark" in the context of this research is defined as standards of provision supportive of student achievement in English and which is worthy of emulation by other schools.

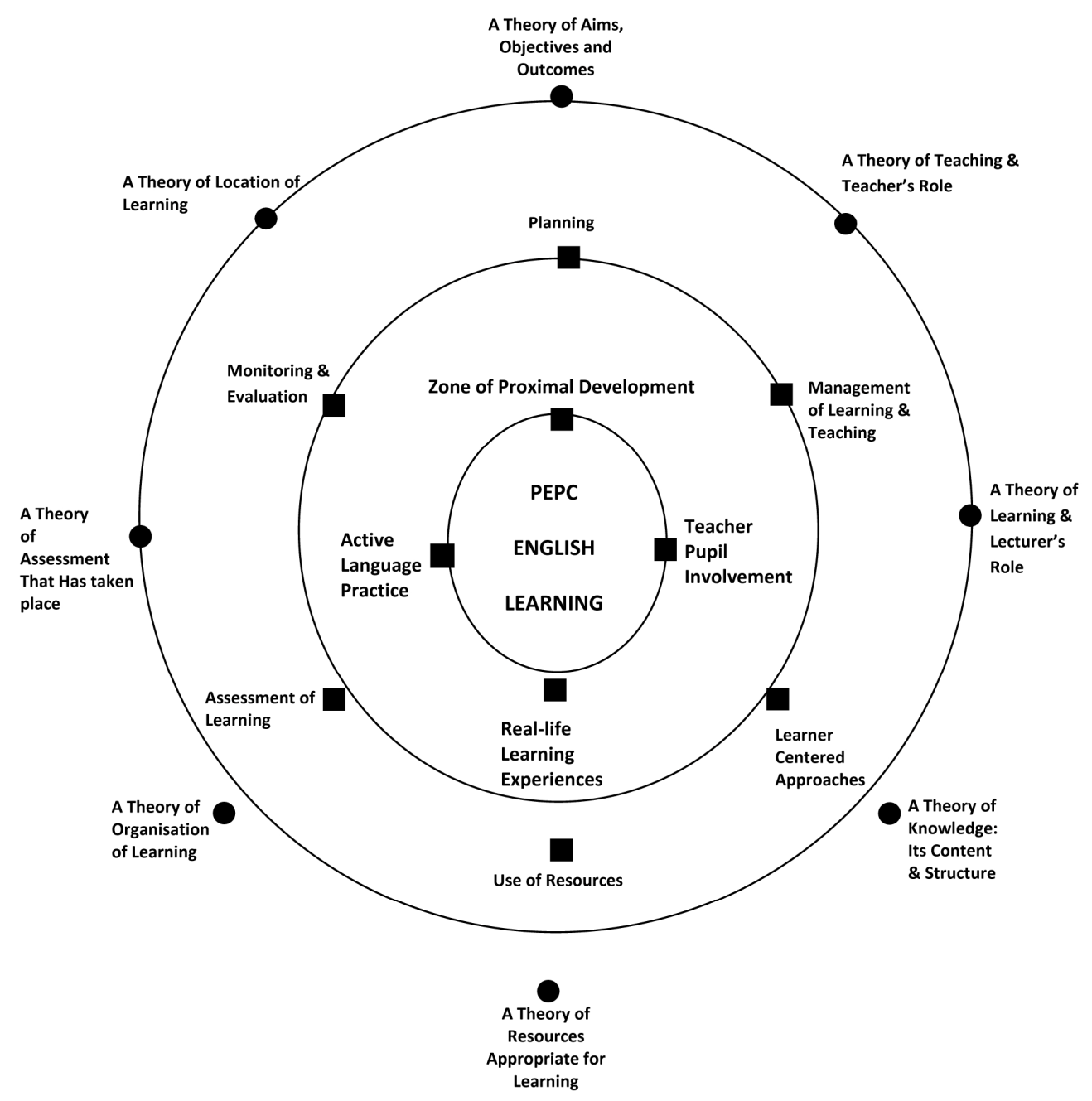

Figure 1. An overview of TESOL quality audit framework 
In the TESOL Audit Framework development process, three interrelated spheres/levels were defined (see Figure 1). The outer most sphere consists of the quality characteristics drawn from the work of Meighan (1986). This set of quality characteristics were used to organise and codify the data collected in the first phase for generation of the framework. The middle sphere shows the modified generic quality characteristics matched against the quality characteristics of Meighan (1986). The inner level boldly states the underlying principles of TESOL found in the schools. Briefly, the first principle, "zone of proximal development" asserts that the teacher should baseline assess the learner's overall language proficiency, other achievements and establish developmental tasks accordingly to take learning forward. The second principle, "teacher-pupil involvement" requires that the sufficient scaffolding provided involves both the teacher and pupils actively in a variety of inter-related tasks and activities. The third principle, "real-life learning experiences" asks to ensure classroom experiences replicate situations outside. The last principle, "active language practice" demands a range of tasks and activities to maximize practice, for example, the use of questions, clues and cues. The review of the selected benchmarks from the TESOL Audit framework is presented below.

\subsection{The Selected Benchmarks (Principles)}

\subsubsection{Zone of Proximal Development}

According to Vygotsky (1978), zone of proximal development (ZPD) is the distance between the actual developmental level as determined by independent problem-solving and the level of potential development as determined through problem-solving under adult guidance or in collaboration with more capable peers. In other words, the ZPD is the distance between current achievement and future potential level of performance (gap in learning). Vygotsky suggests that pupils cannot manage this development on their own. In restating the ZPD concept, Cummins (1996) expressed that simply, the ZPD is the interpersonal space where minds meet and new understandings can arise through collaborative interaction and inquiry. However, Ohta (2005) cautioned that rather than understanding the ZPD as a strictly interpersonal space, it may be more useful to consider how the mechanisms of the ZPD may be internalized over the course of development. To internalize, the teachers as experts and facilitators need to assess pupils' real learning level continuously to scaffold both the pupils and their learning in order to extend their achievement (knowledge and skills) to a higher level competence (MacGilchrist, Myers, \& Reed, 1997).

Lately, the idea of ZPD has been extended to zone of proximal teacher development (ZPTD) and entered teacher education. Warford (2011) elaborates (ZPTD) as the distance between what teaching candidates can do on their own without assistance and a proximal level they might attain through strategically mediated assistance from more capable others (i.e. methods instructor or supervisor). This account suggests that the teachers, while helping to step up the ZPD of the students, need to enhance their own ZPTD as well for strong scaffolding.

\subsubsection{Teacher Pupil Involvement}

ZPD demands that the teacher should manage learning and teaching in a process of guided pupil participation from assisted scaffolding to unassisted performance. Mercer (1995) argues that knowledge is neither accumulated nor discovered by learners, it is shaped by people's joint communicative activities. Cummins (1996) also adds to this context where pupils' identities are being affirmed for effective learning. This suggests that a teacher needs to involve herself by thinking positively that the learners have great potential to learn and provides highly supportive, secure and safe environment (Ofsted, 2012) so that the pupils feel at ease. In a class of thirty, for instance, she needs to beware of 30 different mind maps and cannot afford to ignore them if she wants those children to learn (Bowring-Carr \& West-Burnham, 1997).

To keep all the differentiated pupils motivated, it is often helpful for a teacher to provide a variety of feedback fairly immediately (Hattie \& Timperley, 2007). The pupils should be encouraged to build on current achievement levels by putting them in different groups (Belcher, 2006) and develop their knowledge involving in real-life learning situations (Ellis, 2003). The involvement in such activities forces them to try a task because it is planned and designed in relation to the learning levels of the individual pupils (Tomlinson, 2003). Fletcher (2003) widens the view and defines this principle as meaningful student involvement or the process of engaging students in every facet of the educational process for the purpose of strengthening their commitment to education, community and democracy.

\subsubsection{Real-Life Learning Experiences}

Doughty \& Long (2003) emphasise third principle and state that new knowledge is better integrated into long-term memory, and easier retrieved, if tied to real-world events and activities. This principle desires the teacher to ensure execution of real-life learning experiences. Teachers should try to replicate the past situations 
and experiences in classroom that are familiar to the children for their better understanding. This account lays stress on the past experience of pupils and their critical reflection in context (Krashen, 1988; Cummins, 1996). To help this, there is need for iterative process of action (doing or experiential learning), reflection (assessment) and planning (active language practice). This also suggests that experiential learning is interdependent and a very important part of the cyclic process. Kolb in Robert (1998) sees experiential learning as a cycle of experience, reflective observation, abstract conceptualisation and active experimentation. Holt (1984) too promotes experiential learning and quotes a Chinese proverb: "I hear and I forget, I see and I remember and I do and I understand".

It was observed in the schools, the extensive use of real-life tasks and activities (negotiations, making food items, taking, putting, cutting, peeling, packing, role play, weighing, comparing, model making, baking and so on) provide the pupils with the opportunities to use their previous knowledge, experience and language (mother tongue and English) to make sense of new learning. For example, it was observed that making of a burger in classroom can exploit many of the above experiential steps generating much language in the firsthand experience. These inter-related tasks (Ellis, 2003) help in conservation of learning, and in this contextualized (Krashen \& Terrel, 2000) learning environment (comprehensible input), the pupils have an opportunity to achieve immediate success.

\subsubsection{Active Language Practice}

The fourth principle demands from the teacher provision of a range of learning opportunities maximizing active language practice through the use of a variety of resources and learning and teaching strategies. The teacher, for instance, should manage a process oriented environment (Carless, 2004) in which the pupils are encouraged to extensively speak and listen (active language) through questions, clues, cues, guess, surprise, context, success and creativity. Ur (1988) in (Ellis, 1997) explains active language practice as something by which both explicit and implicit knowledge is automated. This clearly indicates to achieving automation by exploiting a variety of resources including the use of learning and teaching strategies. Ellis (2008) also suggests a balanced approach to achieve focus on form through communicative tasks designed to provide opportunities for learners to practice specific grammatical structures while focused primarily on meaning.

To encourage the pupils, active language practice is further pushed by the use of real-life genres which replicate outside the classroom. To assist this process, Ellis (2000) suggests that the teachers need to use a range of interactive resources and strategies to enhance active language practice including integration of four language skills. Similarly, Cummins (1996) believes that it is crucial to emphasise active language use by students because this not only generates more focused input from teachers and other communication partners but also deepens students' intellectual comprehension of issues (cognitive skills). Utilizing these selected TESOL benchmarks as a framework the Malaysian literature was reviewed.

\subsubsection{Malaysian TESOL Provision}

It was observed that from its commencement period in the late 1950s, the status of English has undergone many phases of development in Malaysia. This provision kept on fluctuating as evidenced below.

"The conversion began in 1965, and as an interim measure a bilingual system was adopted Bahasa Melayu for the Arts subjects and English-medium for science and technology. This bilingual system was changed and the government announced a modification of the policy, calling for a switch to English as a medium of instruction at all levels" (Gill, 2005).

Yao and Raman (2007) also highlight this bilingual provision as follows:

"The Malaysian government decided to introduce English as a language medium to teach Science and Mathematics at all levels of the education system in stages" (Yao \& Raman, 2007).

Consequently, English was implemented for science and mathematics at all the levels. Unfortunately, pupils entering primary schools lacked the requisite background and level of proficiency. Yao and Raman (2007) conclude that most Malaysian children enter primary schools without the required level of CALP (Cognitive Academic Language Proficiency) in English to use it as an effective and functional tool to acquire knowledge. Both the researchers complain about the ineffectiveness of the in-service courses conducted for science and mathematics teachers that they further complicate the implementation of the policy of teaching science and mathematics in English. Nunan (2003) responds about such policy, stating:

“... some significant problems including confusion and inconsistency at the level of policy, particularly regarding the issue of age of initial instruction, inequity regarding access to effective language instruction, inadequately trained and skilled teachers and a disjunction between curriculum rhetoric and pedagogical reality." 
Views about ineffectiveness of teacher education have been stated by Mohd Sofi (2002) and Kamogawa (2010). Similar concerns about declining standards of English among Malaysian students have been shown by Yao \& Raman (2007) and Sham'ah Md-Yunus (2013). In addition, Yao and Raman (2007) also indicate ineffectiveness of teachers and students. Malaysian researchers, while exploring the ineffectiveness, do not consider the root causes of the problem and indicate proper solutions considering TESOL policy and curriculum.

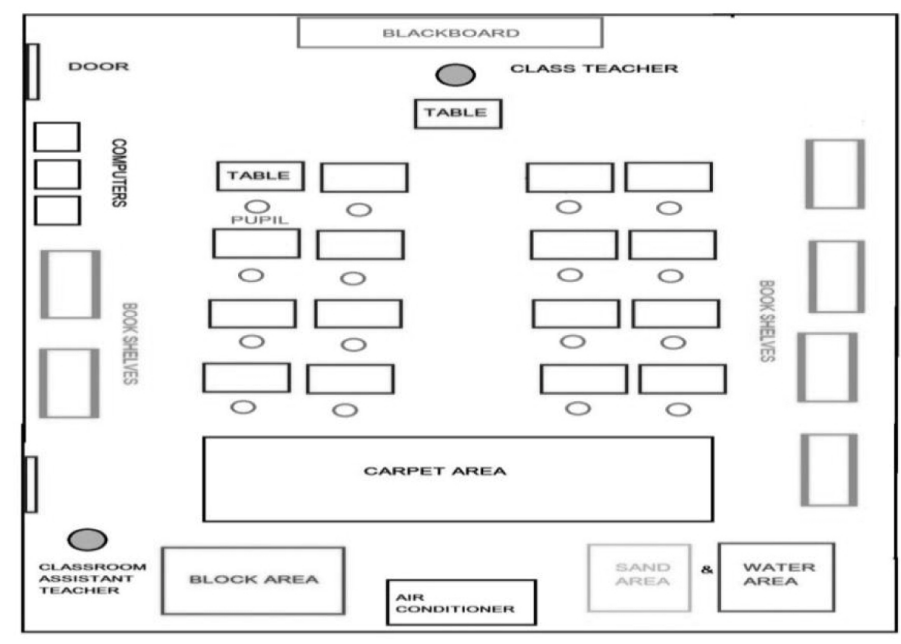

Diagram 1. A typical classroom layout in Malaysia

Diagram 1 depicts a typical classroom layout in Malaysia. The recent Malaysia Education Blue Blueprint (2013) acknowledges and substantiates the above mentioned concerns and directs inclusion of international standards, Bahasa Malaysia and English language, qualified teachers and regular assessments for better performance. This acknowledgement clearly indicates, first, significance of English in Malaysia and secondly, informs about critical gaps in overall TESOL provision that need attention. Moreover, the directives emphasise utility of international standards, bilingual curriculum, qualified teachers (training) and regular assessment (ZPD to scaffolding) for better performance, all of which seem to map quite closely with the selected TESOL Benchmarks discussed. However, the blueprint, while indicating the precise concerns, neither indicates the assessment criteria to find the gaps nor elaborates on steps of implementation in a TESOL setting accordingly. The selected TESOL benchmarks proposed in this research and piloted in Malaysian schools bring in effectuation framework, which is workable and thus complement the gaps.

\section{Methodology}

Despite ongoing issues over comparative methodologies (Raivola, 1985; Oyen 1990; Hantrias \& Mangen, 1996; Phillips \& Schweisfurth, 2006), the intention of the Malaysian pre-school case studies (as detailed in the following) was to determine the extent to which the quality characteristics and standards articulated in the TESOL Quality Audit Framework were present. Phillips \& Schweisfurth (2006) support this cross-educational comparison stating that indeed it is often the cultural, contextual, structural, and functional aspects of education systems which are so fundamentally different as to provide the initial impetus for comparison. In addition, there are immediate contrasts evident in the lack of equivalence that cause the researcher to seek explanations for them in terms of differences in "culture" and "context". In this case, despite the contextual similarities (learners' age, English as additional language and objectives) between the two sites, there were great differences in TESOL approach e.g. traditional vs. progressive.

The home language of the pupils is Bahasa Malaysia, and they are learning English as an additional language. A detailed description of the current TESOL provision in six Malaysian private pre-schools was undertaken following the same benchmarking approach used in the English research (refer to 1.1). A consideration of the comparison was the need of gaining an understanding of the extent to which good TESOL practice in Britain can be adapted appropriately in Malaysian pre-schools. To achieve the above purpose the researcher visited Malaysian private pre-schools (for 4-6 year olds) from February 1999 to September 2000 to carry out the field work. The schools typically had classrooms large enough to hold a class of 30-40 pupils. However, there has not 
been any substantial changes as evident from the Malaysia Education Blueprint (2013).

The choice of pre-schools in Kuala Lumpur and Seremban, (which are two prominent metropolitan cities in Malaysia) was made in the same way as that which occurred in Birmingham, England. That is, the chosen pre-schools ought to be the ones at the forefront of TESOL provision in Malaysia. It was hypothesised that the absence of quality characteristics and standards in these schools were likely to be the situation also in schools not considered as good TESOL schools. If the best cases do not hold, the situation is likely to be even worse in other TESOL schools. These schools were given the fictitious names for maintenance of confidentiality.

The Malaysian research data was collected and analysed on the same basis as that of the Birmingham data. Throughout the research non-participant observations were carried out. That is, the coded lesson observations (thick descriptions), along with evidence collected from the interviews of teachers and head-teachers and school documents, were analysed using the selected TESOL Quality Audit Framework to assess the presence or absence of quality characteristics and standards. A TESOL audit document was then completed by noting the coded moves from the observed classes of all the six schools.

\section{Results}

The completed framework confirmed the poor extent of the quality standards (many gaps of good practice) within each quality characteristic in all the schools. Graph 1 clearly shows wide variations between the benchmarks and Malaysian Schools based upon the four principles. It shows maximum moves of ZPD, teacher-pupil involvement, real-life learning experience and active language practice depicting the importance given to these principles. Malaysian schools show minimum coded moves because they seem to follow typical conventional approach.

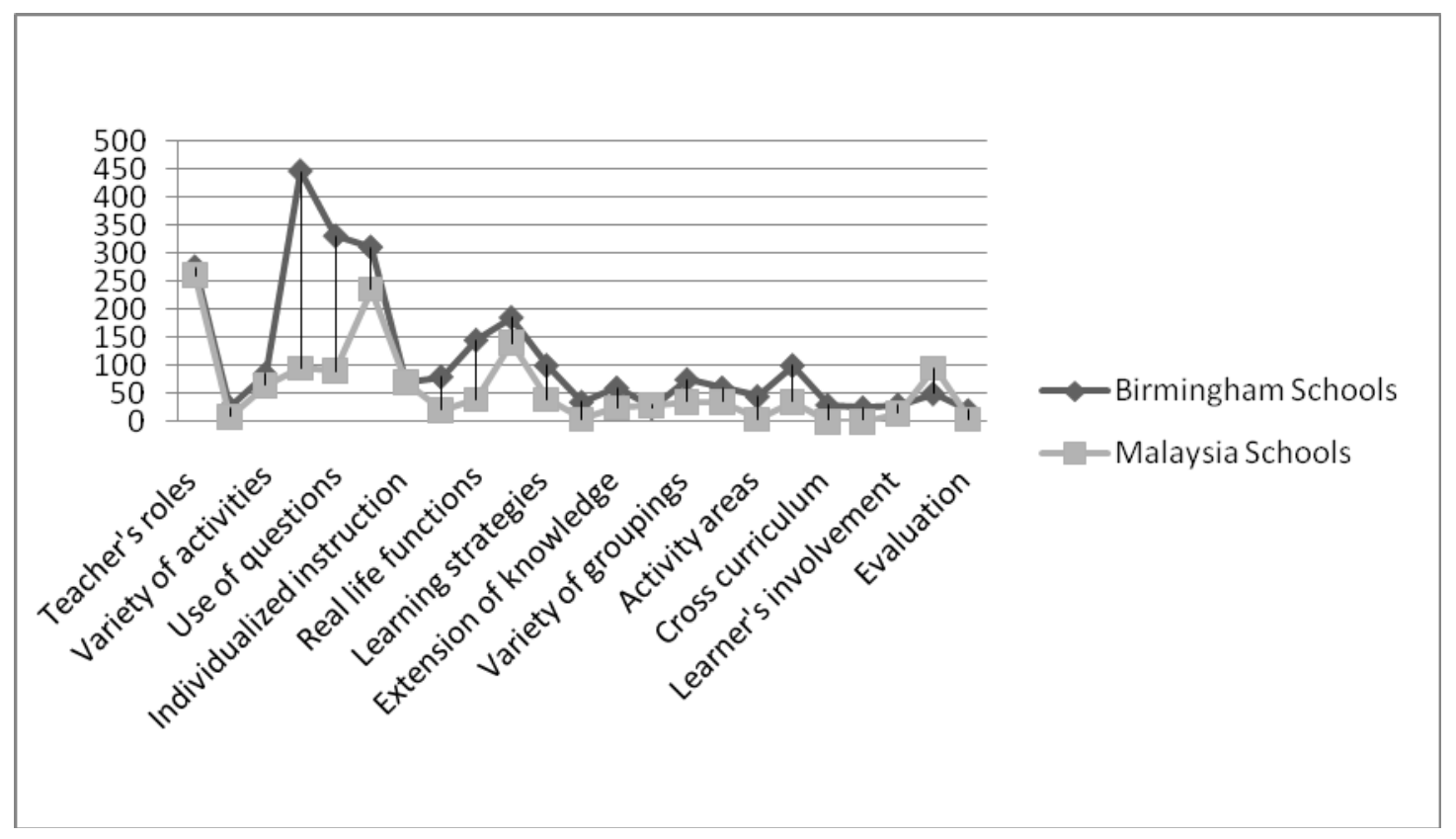

Graph 1. Management of learning and teaching in Birmingham and Malaysian schools

The graph also shows minimum moves of questions and answers in Malaysia. The Malaysian schools used prescribed textbooks, remained examination oriented, and teacher centred approaches dominated (field notes, 2000). The benchmarking process proved existence of subtle and wide differences which were presumed before the start of the initial study (literature review). The graph also shows the extent within a quality standard of process environment that comprises mainly variety of tasks and use of questions to accelerate learning. This supports effectiveness of process environment and negates product environment implicitly. To summarise, a brief comparison of the selected benchmarks and Malaysian schools' practice is presented in the following dichotomy. 
Table 2. Benchmarks and Malaysian schools' practice dichotomy

\begin{tabular}{|c|c|}
\hline Benchmarks & Malaysian Schools \\
\hline Start from measuring ZPD & No proper diagnosis \\
\hline Comprehensive scaffolding & Restricted scaffolding (use of textbooks) \\
\hline $\begin{array}{l}\text { Encounter real life experiences (More } \\
\text { Experiential) }\end{array}$ & $\begin{array}{l}\text { Follow transmission of knowledge approach (Less } \\
\text { Experiential) }\end{array}$ \\
\hline Follow social constructivism approach & Maintain conventional (teacher fronted class) \\
\hline $\begin{array}{l}\text { Teacher's multiple roles (e.g. learner, questioner, } \\
\text { actor, supervisor, parent \& demonstrator) }\end{array}$ & $\begin{array}{l}\text { Teacher's limited roles (e.g. instructor, monitor \& } \\
\text { demonstrator) }\end{array}$ \\
\hline Multi Adult Support & No Adult Help \\
\hline $\begin{array}{l}\text { Use of interactive topics to realise objectives of } \\
\text { the curriculum (systemic) }\end{array}$ & $\begin{array}{l}\text { Limited topics to cover curriculum (Separate Subjects) } \\
\text { (systematic) }\end{array}$ \\
\hline Use of variety of teaching \& learning strategies & $\begin{array}{l}\text { Use of mainly Rote and Learning and Translation } \\
\text { Method }\end{array}$ \\
\hline $\begin{array}{l}\text { Extensive variety of interactive resources and } \\
\text { help materials }\end{array}$ & Limited resources (mainly textbooks and charts) \\
\hline
\end{tabular}

\section{Application of Selected Benchmarks}

The graph and dichotomy indicate clearly the gaps in Malaysian TESOL provision which can be used as a baseline for use of application of the four principles. There is a dire need to develop TESOL curriculum that addresses the present weaknesses. A fit-for-purpose curriculum not only incorporated the requirements of Malaysia Education Blue-print (2013), but also National Curriculum for (4-6 year olds). The formulation of TESOL curriculum based upon the four principles also included intercultural (McKay, 2002), trans-lingual (Pennycook, 2008) and intra-lingual (Charteris-Black, 2002) aspects.

The application of curriculum incorporated the project management best practices especially vision, mission and key performance indicators drawn from (eghrmis, 2000). Since there was a transition from the present state (quality deficiencies) to future (a better quality state), best practices of managing change in mindset, transformation, realization and continuous improvement were also considered. This gave rise to a whole and holistic curriculum focusing on progressive approach (Bennet, 1976) was prepared to address TESOL issues pertaining to multi-ethnic students including that of the indigenous minority communities.

Briefly, piloting of this curriculum project was carried out in two private schools in Malaysia for one year to see effectiveness, consistency and uniformity of instruction. The main emphasis was on students' active learning and teachers' hands-on-training based upon the progressive style. The process comprised review and revision (benchmarking) before formal implementation through hands-on-training, close observation of teachers and utilization of parents' feedback. After one semester it was felt that sporadic use of real-life experiences was not comprehensive and had a little impact. Consequently, to improve the instructions one-day real-life projects were documented, implemented and updated to tie the knots of the four benchmarks together through maximum interrelated tasks and activities. This constructive approach helped the children to learn fast and provided hands-on-training for the teachers involved in the learning and teaching process.

Eighty (80) one-day real-life projects as a tool helped to improve Malaysian TESOL provision to a great extent. The curriculum has sustained to-date, facilitating learning of both the children and teachers. The pictures of the real objects are displayed on the wall in a sequence to be followed by the teachers and pupils. This enables them to know annual, termly, weekly and daily planning (Neil, Jawaid, \& Jaswinder, 2000). These projects, though simple for starters, lead towards performance of a variety of inter-related tasks and activities (Ellis, 2003) and hands-on training for active learning, thinking and communicative skills. They are easy and interesting, enjoyed by the children since they are very familiar real-life activities occurring frequently. These simple processes are foundation for more complex processes that are part and parcel of future education, utilizing Information and Communication Technology (ICT) and e-projects. Doughty \& Long (2003) support this idea by stating that new knowledge is better integrated into long-term memory and easier retrieved, if tied to real life functions. These functions tie together all the four benchmarks in a systemic and systematic manner. 


\subsection{One-Day Real-Life Project-Based TESOL Provision}

This One-day Real-life Project-Based TESOL Provision is based upon four cyclic highly interactive principles, crucial for enhanced learning and continuous improvement of the pupils. The whole cyclic learning journey comprises reflection, interactive breakfast, guessing time, English and Bahasa Malaysia session, project time, mathematics and science session, food time, Islamic or Moral Studies, story time and finally handing in the homework. A detailed account of this one-day journey is provided in a flowchart as shown below.

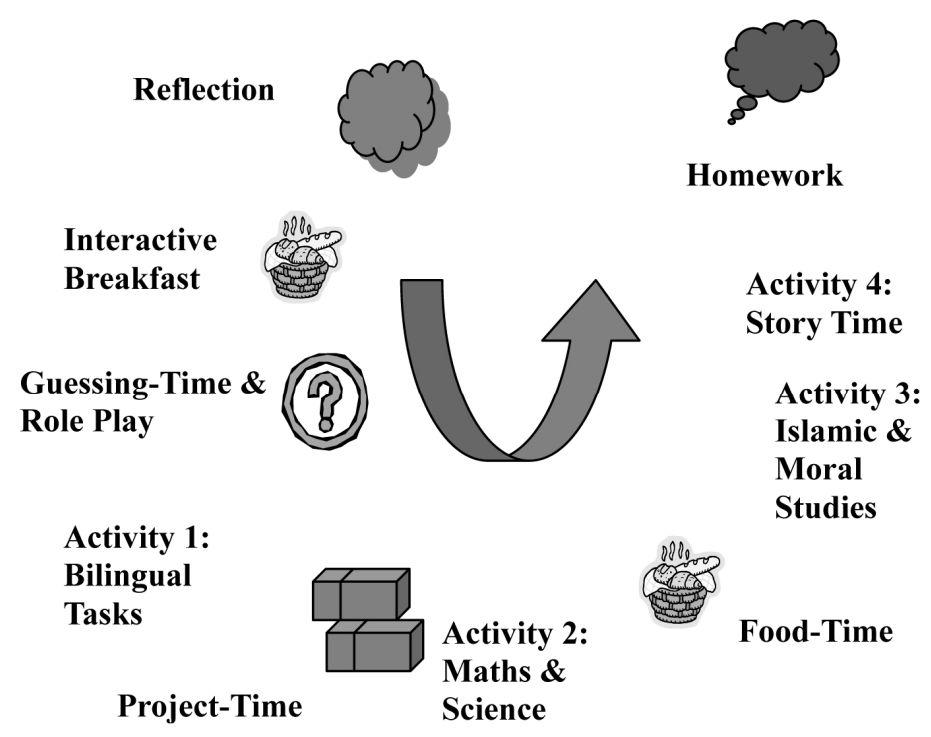

Flowchart 1. One day real life TESOL project cycle

This approach demonstrates how different aspects of the pre-school/primary National Curriculum such as mentioned above can be integrated in the learning journey. The day commences with reflection (discussion of homework and yesterday's project) morning prayers and light physical exercises. Then the children sit on carpet and the teacher discusses, the particular day's project (e.g., changing bun to burger). After that, the children halt for a very interactive breakfast where they learn how to appreciate, request, offer and share.

Trans-lingual aspects help to untie the children's tongue for English. Words of similar sounds in both Bahasa Malaysia and English were selected as "starters". Frequently used real objects such as apple (epal), bun (ban), cake (kek), ice-cream (ais-krim), jelly (jeli), mango (manga), orange (oren), tomato sauce (sos tomato) and zip (zip) are exploited in the first round. These familiar contents prepare the pupils progressively up to unfamiliarity and gradually move them to more challenging tasks. Moreover, use of mother tongue is encouraged initially as a transition strategy to facilitate motivation, confidence building, language use, and to initiate interaction. This transition strategy works well for these children.

Guessing time and other activities facilitate children's thinking and linking competence. After that they see teacher demonstrating e.g. making of a burger. Teacher: "Today we will make ..." The pupils: burger. Teacher: very good, you are right, you are pandai (intelligent). The children guess correctly because they can see the sequence of the projects on the wall. The same demonstration is carried out by the children one by one (role play). Then they do English and Bahasa Malaysia worksheet. The contents include one simple contextualized poem. For instance: "burger, burger, my burger, your burger, our burger, their burger, his burger and her burger". During the rendering of poem they exchange the real burger. The children act it out and pass the burger on from one to the next sitting in line on the carpet. They enjoy very much this play-way method of language learning.

Subsequently, the pupils move on to the academic path, where they listen, observe, follow, perform, think, explore, speak, reflect, read and write (integration of skills). The children work on science worksheet that emphasises core ideas: name, colour, size, smell, taste, shape and so on of bun and burger. Science is followed by interactive mathematics worksheet that emphasizes e.g. "I have one bun". "I add one more". "Now, I have two buns/I have two". Both the subjects are taught through Bahasa Malaysia as well to enhance learning by 
understanding. Interactive food time repeats the same simple and most common language structures of the breakfast. Immediately, after that, Islamic Studies takes place with the question and answer session. For example, "who gives you burger?" Everyone answers "Allah (God) gives me burger" (of course, initially with the help of the teacher).

Limited computer work is followed by recitation of experiential stories (real-life functions) by the teachers and pupils individually and in chorus. This provides the children with time for self-expression and creative thinking. Every day a new project commences but learning journey follows the same sequence of tasks and activities. After every four week days, the fifth day (Friday) revision is carried out to revise all the four real-life projects. The pupils perform comparisons (e. g. bun/ball, apple/orange), on this day besides routine tasks and activities.

These "real-life projects" similarity in sequential process helps a majority of the average children to recognise and practise language structures and vocabulary with ease. This revision also informs about different zones of proximal development. Reading is facilitated by clear and vivid pictures (see below). Each process is a learning experience that is very simple, easy to perform and narrate. For very early learners (readers), the attractive pictures encourage them to start through picture reading. MY FUN PAGE ${ }^{\mathrm{TM}}$ is essentially one-page homework for reinforcement and continuity of learning. The resources to sustain continuous learning include project outcome (e.g. a pack of burger made during the project time), the fun page, the burger story and a thinking task for vocabulary building. In this manner, their classroom learning is reinforced and strengthened at home. The following bilingual (English and Bahasa Malaysia) account illustrates a real-life project of making a burger.

Table 3. Demonstrate, speak and read

Burger Making Process

\begin{tabular}{|c|c|}
\hline What is this? (Ini apa?) & This is bun. (Ini ban). \\
\hline $\begin{array}{l}\text { Tell me its colour? (Beri tahu saya } \\
\text { warna apa?) }\end{array}$ & $\begin{array}{l}\text { The bun is brown. (Ban itu warna } \\
\text { coklat). }\end{array}$ \\
\hline $\begin{array}{l}\text { Tell me its shape? (Beri tahu saya } \\
\text { bentuk apa?) }\end{array}$ & $\begin{array}{l}\text { The bun is round. (Ban itu } \\
\text { berbentuk bulat). }\end{array}$ \\
\hline $\begin{array}{l}\text { Tell me its size? (Beri tahu saya saiz } \\
\text { apa?) }\end{array}$ & The bun is big. (Ban itu besar). \\
\hline $\begin{array}{l}\text { Can you make burger? (Boleh buat } \\
\text { burger?) }\end{array}$ & $\begin{array}{l}\text { I can make burger. (Saya boleh } \\
\text { buat burger). }\end{array}$ \\
\hline $\begin{array}{l}\text { How do you make burger? } \\
\text { (Bagai-mana anda buat burger?) }\end{array}$ & $\begin{array}{l}\text { I take bun. (Saya ambil ban). } \\
\text { I cut the bun. (Saya potong ban). }\end{array}$ \\
\hline How many pieces? (Berapa keping). & $\begin{array}{l}\text { I have two pieces. (Saya ada dua } \\
\text { keping). }\end{array}$ \\
\hline $\begin{array}{l}\text { I put egg on it. (Saya letak telur di atas } \\
\text { ban). }\end{array}$ & $\begin{array}{l}\text { I put salad on it. (Saya letak salad di } \\
\text { atas ban). }\end{array}$ \\
\hline $\begin{array}{l}\text { I put tomato sauce on it. (Saya letak } \\
\text { sos tomato). }\end{array}$ & $\begin{array}{l}\text { I put bun on top. (Saya letak ban di } \\
\text { atas ban). }\end{array}$ \\
\hline What is this? (Ini apa?) & $\begin{array}{l}\text { This is my burger. (Ini burger } \\
\text { saya). }\end{array}$ \\
\hline
\end{tabular}

\section{Discussion}

A careful application of the selected benchmarks provided the elements in the One-Day Real-life Project Based Learning Cycle that beautifully integrates all the four core benchmarks: "zone of proximal development", "teacher-learner involvement", "realistic learning experiences" and "active language practice". The cycle has also incorporated requirements of Malaysia Education Blueprint (2013) and the pre-school National Curriculum successfully. The following account discusses in detail the application of the selected TESOL benchmarks. 


\subsection{Zone of Proximal Development}

The implementation of this approach for more than ten years in the selected pre-schools indicates that it is imperative to assess a range of pupils' capabilities, including knowledge, concept pool, culture, learning styles, home language and home-background as a bases for planning and promoting learning. This has also been emphasized by Neil, Jawaid, and Jaswinder (2000) who state that teachers need a comprehensive assessment so that they remain current with the achievement level of each and every pupil in the class. First, the teachers must acknowledge that a child is not a non-speaker rather a good speaker of his mother tongue. Second, he is literate in his mother tongue. They should capitalize on the skills that he has. That is the reason why in the one-day learning cycle mother tongue has been given importance. Hall and Cook (2012) promote the use of mother tongue to break the silence of a new learner. On each learning day, the teachers carry out daily assessment which is embedded in the daily planning sheet, place pupils in three appropriate groups (not-yet-independent, going-to-be-independent and independent), discuss progress of each pupil weekly and set the target for next week. The head teacher solves assessment and other problems faced by the teachers. This weekly review and evaluation proved very effective to step up the children's learning. MacGilchrist, Myers, and Reed (1997) emphasise that the teacher has a proactive role and has to make the correct analysis of where the pupils are and then provide appropriate scaffolding for learning, whilst Warford (2011) also supported the teachers' proactive role by suggesting enhancement of their zone of proximal teacher development (ZPTD).

\subsection{Teacher-Pupil Involvement}

It was observed that the teachers involve the pupils from assisted guidance to unassisted performance. They have high expectations of the learners' potential to learn. To keep pupils motivated, it is often helpful for teachers to provide a variety of feedback (praise, prize and recognition) fairly immediately (Susan, 2008). The project contents are loaded with vivid pictures emphasising learners' self, immediate family and frequently occurring real-life inter-related tasks and activities. However, the main focus, remains on "oracy", "literacy" and "numeracy" in basic English based upon the key objectives of the NC for preschool (Pra-Sekolah). The interactive projects also help the teachers to observe, watch and monitor the learning strategies of the learners and they provide a comprehensible language input (Krashen \& Terrel, 2000) easy for the learners to internalise the content and move to independence.

The Project-Based interrelated tasks and activities involve the children actively. They learn to analyse, synthesise, and make sense and connections. These tasks are seen as a vehicle for not only the development of language and understanding but also strengthening commitment to education (Fletcher, 2003). The core ideas to step up language learning are drawn from thinking and linking skills. These ideas get strengthened when a child is provided with an active learning environment by the teachers consistently. Key questions involving elements of what, why, how, when, where and who provide a variety of thinking and linking processes at various levels. For instance, initial WHAT questions probably require a very low level thinking but a WHY question requires a higher level of analyzing and synthesizing process. It is worth mentioning that initially, one-word answers are acceptable but with a view to extend them later on. These skills are activated during reflection, guessing, sequencing and problem solving activities, linking language and academic (cross-curricular) skills which are important for achieving success in life.

\subsection{Use of Real-Life Learning Experiences}

The One-Day Real-life Based Projects ensure very close interaction of standards of learning and uniformity of instruction by linking closely the remaining three benchmarks. It has been observed that the teachers through repeated interaction with these projects, start discussing, managing and reviewing situations and events familiar to the children outside the classroom or school. They involve the pupils to act out and discuss real-life functions (Belcher, 2006) and assess their language proficiency continuously (ZPD). Real food items, for example, are brought in the class. The making of a burger, is carried out and explained as a number of steps (tasks) e.g. washing, cutting, grating, organising, displaying, decorating, waiting, packing, distributing and eating. In carrying out all the above experiential steps (the documented thematic stories), much language is generated (with specific structures and vocabulary) as firsthand experience. Each thematic story is a window to a larger theme: Bun, for instance, is an element of the larger theme, food. Food, on the other hand, is part of a more complex theme, fast food. Thus it makes room for multiple consistent themes instead of "one topic, one term" (Field Notes, Birmingham, 1998).

Moreover, the teachers get an opportunity to demonstrate, discuss and repeat sequential tasks to develop interactive, communicative and cognitive competence. In this contextualised learning environment, all the pupils have the opportunity to participate in graded tasks. This often motivates and helps the pupils to progress through 
action and discovery in a supported contextualised environment. Each process is a learning experience that is very simple, easy to perform and narrate after the occurance. The attractive pictures all around the room and in the readers encourage early learners to read through familiar action pictures. These real stories (real tasks) incorporate a number of features that help to increase the speed of reading such as repeated use of similar and familiar words, use of similar sounds in English and Bahasa Malaysia (as mentioned above), use of real objects, narration of real-life functions and use of clear pictures of each event and action performed during the execution of a specific project. The simple projects seem to provide opportunities for fast and integrated learning, effective thinking and linking, sustained teacher-pupil involvement, lively experiential learning, replication of real negotiations (Belcher, 2006) and practice of interactive communicative language.

\subsection{Active Language Practice}

It was also noticed that the teachers utilize the three preceding benchmarks by trying to manage a process oriented environment (Piller \& Skillings, 2005) in which the pupils are encouraged to extensively speak and listen through questions, clues, cues, guess, surprise, context, success and creativity. This clearly suggests that to achieve automation of learning both learner centred as well as teacher centred approaches need to be used together. Active language practice comprises a range of inter-related meaningful tasks, situationally based and developed on a daily project basis. For instance, to initiate "talk", the teachers simplify their language and style (Carless, 2004), apply a variety of teaching and learning strategies (Chowdhury, 2003) and teach English using cross-curricular subjects such as mathematics, science and many other subjects (PSNC, 2003). Active language practice is further pushed by the use of real life genres (Wedell, 2005), which replicate experiences outside the classroom and school environment. In this way learning both inside and outside school is integrated for live, active and interesting learning climate (Mullock, 2006).

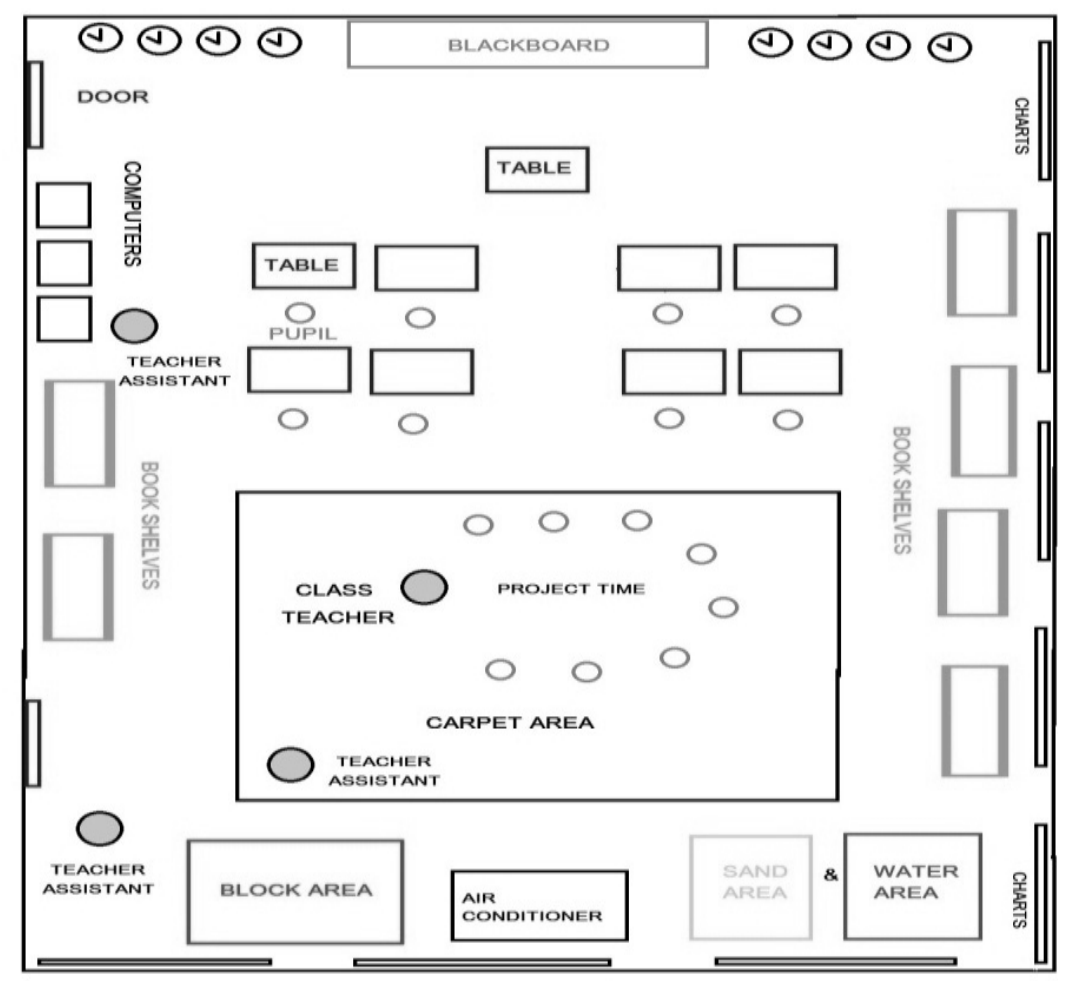

Diagram 2. A progressive classroom

To enhance this practice, the teachers also use a range of resources such as use of mother tongue, language games, pictures, stories, learning areas (Diagram 2), real and familiar objects, computer, video/audio equipment and role play to enhance not only interaction but also thinking (Littlewood, 2004). This not only provides a variety in practice but also extends pupils' knowledge through immense motivation and confidence. Carless (2004) also stresses to manage a process oriented environment in which the pupils are engaged in extensive speaking and listening. To sustain this practice outside the classroom homework package is compulsory for children to take home. The resources in the package include project outcome (e.g. a pack of burger made during 
the project time), the Fun Page, the story and a thinking task for vocabulary building. For example, MY FUN $\mathrm{PAGE}^{\mathrm{TM}}$ is essentially one-page for reinforcement and continuity of learning. The practice continues with the parents/sibling(s) at home when both parents and children reflect upon the day's journey using the page and project story. Invariably, some of the parents' lukewarm behaviour towards the homework affects children's learning adversely. The Diagram 2 above depicts the progressive style of classroom situation maximizing language and learning skills.

\section{Conclusions and Recommendations}

The focus of the paper was to inform the readers about the benchmarking in TESOL as a research method to identify "fit-for-purpose" benchmark framework for countries where English is used as an additional language. First phase of benchmarking helped to formulate initial benchmarks and subsequently through thick description and triangulation method they were validated to be used for improvement of a variety of TESOL situations. The Malaysian TESOL situation was researched based upon the same benchmarking (phase 1) process to identify the gaps (quality deficiencies). The process comprised literature review, field notes, thick description (detailed observations), interviews with teachers and head teachers, and policy document analysis including Malaysia Blueprint document (2013). "Fit-for-purpose" benchmarks (four principles) were applied to improve TESOL provision. To tie all the four principles together, one-day real-life project based TESOL provision was piloted and tried in two private schools. Consequently, it was observed that these projects proved very interesting for the Malaysian children and the teachers who are concerned to alter traditional classroom practice to progressive style. The implementation of the selected benchmarks showed that there were obvious changes in the pupils' work and achievement.

These inter-related and interesting tasks and activities (Walqui, 2006) are very simple, familiar, and children see the manufacturing process happening in the classroom, market and at home every day. This reinforces their learning outside the class. These real-life projects provide real, interactive and experiential stories for younger children. Undoubtedly, these are exciting tasks and activities that the children can have fun trying with class teachers in school and parents/sibling(s) at home. Children's active involvement motivates them to speak and read with confidence and joy because they experience these real stories before reading activity. The use of both languages English and Bahasa Malaysia is encouraged to facilitate initial confidence building. Moreover, these functions are in line with the Malaysia Education Blue-print (2013) and National Curriculum for Pre-school Education (Dokumen Standard Kurikulum Pra-Sekolah, 2011).

These projects accommodate effectively the four selected TESOL benchmarks as well as transitions based upon intercultural, trans-lingual and intra-lingual (familiar words to phrases to sentences to paragraphs) aspects explicitly. The potential users of these benchmarks comprised preschool and primary school children, teachers, TESOL teachers, curriculum policy and English curriculum coordinators, trainee preschool and primary school teachers, ministries and departments dealing with pre-schoolers and younger children.

The audit indicated that Malaysians need to reconsider the fundamental approach of pre-school TESOL. They should redefine the roles of teachers, pupils, resources, and classroom and school environment in the light of the TESOL Quality Audit Framework. In these changes, the four TESOL benchmarks should be effectively planned and provided for. The adoption of this approach can be of very low cost or no cost initially because it does not necessarily require a huge capital outlay. The improvement plan for Malaysian schools is provided below.

First, "Fit-for-purpose" cyclic benchmarks (Zone of Proximal Development, Teacher Pupil Involvement, Real life experiences and Active Language Practices) may be considered to improve preschool TESOL provision. To integrate all the four benchmarks together, one-day real-life project based TESOL cycle seems fit for Malaysian pre-schools as it has been implemented for more than ten years. Second, the teachers need to exploit the real-life functions and related stories that integrate the whole content and language use. This exploitation is a very good source of the teachers' hands-on-training at the same time. Finally, the Malaysians may consider administering periodic cyclic TESOL Benchmark Audit as an effective strategy to review, identify gaps and develop action plans for continuous improvement.

\section{References}

Belcher, D. D. (2006). English for Specific Purposes: Teaching to Perceived Needs and Imagined Futures in Worlds of Work, Study, and Everyday Life. TESOL Quarterly, 40(1), 133-156. http://dx.doi.org/10.2307/40264514

Bendell, T., Boulter, L., \& Kelly, J. (1993). Benchmarking for Competitive Advantage. London: Pitman.

Bennet, N. (1976). Teaching Styles and Pupil Progress. London: Open Books. 
Bowring-Carr, C., \& West-Burnham, J. (1997). Effective Learning in Schools: How to Integrate Learning and Leadership for a Successful School. London: Pitman.

Brumfit, C., \& Coleman, H. (1995). Talking Shop: Professional Standards in ELT. ELT Journal, 49(2), 176-184.

Carless, D. (2004). Issues in Teachers' Reinterpretation of a Task-Based Innovation in Primary Schools. TESOL Quarterly, 38(4), 639-662. http://dx.doi.org/10.2307/3588283

Charteris-Black, J. (2002). Second Language Figurative Proficiency: A Comparative Study of Malay and English. Applied Linguistics, 23(1), 104-133. http://dx.doi.org/10.1093/applin/23.1.104

Chowdhury, M. R. (2003). International TESOL Training and EFL Contexts: The Cultural Disillusionment Factor. Australian Journal of Education, 47(3), 283-302. http://dx.doi.org/10.1177/000494410304700307

Codling, S. (1994). Benchmarking. In D. Lock (Ed.), Gower Handbook of Quality Management (2nd ed.). Aldershot: Gower.

Cummins, J. (1996). Negotiating Identities: Education for the Empowerment in a Diverse Society. Ontario, CA: California Association for Bilingual Education.

Dahlgaard, J. J. et al. (1994). Advances in Total Quality Management. Abingdon: Carfax.

Dale, D., \& Cooper, D. (1992). Total Quality and Human Resources. Oxford: Blackwell.

Dave, \& Willis, J. (2007). Doing Task-based Teaching. Oxford: Oxford University Press.

Dearing, R. (1994). The National Curriculum and its Assessment: Final Report. London: School Curriculum and Assessment Authority.

Doherty, G. D. (Ed.). (1994). Developing Quality Systems in Education. London: Routledge.

Doughty, C. J., \& Long, M. H. (Eds.). (2003). The Handbook of Second Language Acquisition. Oxford: Blackwell. http://dx.doi.org/10.1002/9780470756492.fmatter

Ellis, R. (1997). SLA Research and Language Teaching. Oxford: Oxford University Press.

Ellis, R. (2000). Task-based Language Learning and Pedagogy. Oxford: Oxford University Press. http://dx.doi.org/10.1177/136216880000400302

Ellis, R. (2003). Task-based Language Learning and Teaching. Oxford: Oxford University Press.

Ellis, R. (2008). Principles of Instructed Second Language Acquisition. CAL Digest. University of Auckland: Center for Applied Linguistics. Retrieved January 13, 2014, from http://www.cal.org/resources/digest/instructed2ndlang.html

Fielding, M. (2001). Students as Radical Agents of Change. Journal of Educational Change, 2(3), 123-131. http://dx.doi.org/10.1023/A:1017949213447

Fletcher, A. (2003). Stories of Meaningful Student Involvement. HumanLinks Foundation: Freechild Project. Retrieved January 3, 2014, from http://www.soundout.org/

Geertz, C. (1973). The Interpretation of Cultures. London: Hutchinson.

Gill, S. K. (2005). Language Policy in Malaysia: Reversing Direction. Language Policy Journal, 4(3), 241-260. http://dx.doi.org/10.1007/s10993-005-7859-9

Glaser, B., \& Strauss, A. (1967). The Discovery of Grounded Theory. Chicago: Aldine.

Grainger, P. (1994). Managing Resources. London: Kogan Page.

Hall, G., \& Cook, G. (2012). Own-Language Use in Language Teaching and Learning. Language Teaching, 45(3), 271-308. http://dx.doi.org/10.1017/S0261444812000067

Holt, J. (1964, 1982, 1984). How Children Fail (Revised ed.). London: Penguin.

Hantrais, L., \& Mangen, S. (1996). Methods and Management of Cross-National Social Research. In L. Hantrais (Ed.), Cross-National Research Methods in Social Science (pp. 1-12). London: Pinter.

Harrington, J. H. (1997). The Fallacy of Universal Best Practices. TQM Magazine, 9(1), 61-75.

Hattie, J., \& Timperley, H. (2007). The Power of Feedback. Review of Educational Research, 77(1), 81-112. http://dx.doi.org/10.3102/003465430298487

Jawaid, A. (1998). A Framework for the Improvement of TESOL Curriculum in Lahore, Pakistan, based upon a Comparative Analysis of TESOL in Birmingham, U.K. (Unpublished doctoral thesis). University of 
Wolverhampton, Walsall, UK.

Jawaid, A. (2014). TESOL Quality Audit Framework: Benchmarking for Curriculum Improvement. University Malaysia Sarawak: UNIMAS Publisher.

Kamogawa, A. (2010). Early Childhood Education in Malaysia: A Comparison with Japan. Retrieved December 10, 2013, from http://www.childresearch.net/projects/ecec/2010_05.html

Korath, L. F. (1993). Auditing Concepts and Application: ARisk Analysis Approach. New York: West Publishing.

Krashen, S. D. (1988). Second Language Acquisition and Second Language Learning. Hemel Hemstead: Prentice Hall.

Krashen, S. D., \& Terrel, T. D. (2000). The Natural Approach: Language Acquisition in the Classroom. Essex, England: Longman.

Littlewood, W. (2004). The Task-Based Approach: Some Questions and Suggestions. ELT Journal, 58(4), 319-326. Oxford University Press. http://dx.doi.org/10.1093/elt/58.4.319

Macgilchrist, B., Myers, K., \& Reed, J. (1997). The Intelligent School. London: Paul Chapman.

McKay, S. (2002). Teaching English as an International Language: Rethinking Goals and Approaches. Oxford: Oxford University Press.

Meighan, R. (1986). A Sociology of Educating (2nd ed.). London: Cassell.

Mercer, N. (1995). The Guided Construction of Knowledge: Talk among Teachers and Learners. Clevedon: Multilingual Matters.

Ministry of Education, Malaysia. (2011). Kurikulum Standard Prasekolah Kebangsaan, Dokumen Standard Kurikulum Prasekolah 2011. Retrieved February 10, 2014, from http://www.moe.gov.my/

Ministry of Education, Malaysia. (2013). Malaysia Education Blue-print 2013: Preliminary Report 2013-2025. Retrieved December 10, 2013, from http://www.moe.gov.my/en/pelan-pembangunan-pendidikan-malaysia2013-2025

Ali, M. S. (2002). Professional Development of ESL Teachers in Primary School. Jurnal Pendidikan IPBA, 2(5), 43-62.

Moreland, N., Jawaid, A., \& Dhillon, J. (2000). Quality Improvement in the TESOL Curriculum: A Generic Benchmarking Approach. Quality Assurance in Education, 8(2), 57-62. http://dx.doi.org/10.1108/09684880010325484

Moreland, N., \& Horsburgh, R. (1992). Auditing: A Tool for Institutional Development. Vocational Aspect of Education, 44(1), 29-42.

Mullock, B. (2006). The Pedagogical Knowledge Base of Four TESOL Teachers. The Modern Language Journal, 90(1), 48-66. http://dx.doi.org/10.1111/j.1540-4781.2006.00384.x

Public Schools of North Carolina. (2003). The Balanced Curriculum: A Guiding Document for Scheduling and Implementation of the NC Standard Course of Study at the Elementary Level. Retrieved January 14, 2014, from http://ncpublicschools.org/curriculum

Nunan, D. (2003). Second Language Teaching and Learning. Boston, Massachusetts: Heinle.

Ofsted, U. K. (2012). Outstanding Achievement for Pupils Learning English as an Additional Language: Greet Primary School. Retrieved January 17, 2014, from http://www.ofsted.gov.uk/resources/

O'Hanlon, C. (1996). Professional Development through Action Research in Educational Settings. London: Falmer Press.

Ohta, A. S. (2005). Inter-language Pragmatics in the Zone of Proximal Development. System, 33, 503-517. http://dx.doi.org/10.1016/j.system.2005.06.001

Oyen, E. (1990). Comparative Methodology: Theory and Practice in International Social Research. London: Sage.

Pennycook, S. (2008). English as a Language always in Translation. European Journal of English Studies (EJES), 12(1). http://dx.doi.org/10.1080/13825570801900521

Phillips, D., \& Schweisfurth, M. (Eds.). (2006). Comparative and International Education: An Introduction to Theory, Method, and Practice. London: Continuum. 
Piller, B., \& Skillings, M. (2005). English language teaching strategies used by primary teachers in one New Delhi, India school. TESL-EJ, 9(3). Retrieved January 21, 2014, from http://www.teslej.org/ej35/cf.pdf

Pike, J., \& Barnes, R. (1996). TQM in Action: A Practical Approach to Continuous Performance Improvement (2nd ed.). London: Chapman \& Hall.

Raivola, R. (1985). What is Comparison? Methodological and Philosophical Considerations. Comparative Education Review, 29(3), 362-374.

Reichart, K., Tomanek, U. H., \& Rappoport, A. (2008). Multi-task Active Learning for Linguistic Annotations. Proceedings of the Association for Computational Linguistics (ACL) (pp. 861-869). ACL Press.

Sallis, E. J. (1996). Total Quality Management in Education. London: Kogan Page.

Savignon, S. (1993). Communicative Language Teaching: State of the Art. In S. Silberstein (Ed.), State of the Art TESOL Essays: Celebrating 25 Years of the Discipline (pp. 35-51). Alexandria: VA.

Md-Yunus, S. (2013). Early Education and Development in Malaysia: Issues and Challenges in Providing a Framework for a Multiethnic Society. Retrieved January 10, 2014, from http://www.childresearch.net/projects/ecec/

Susan, M. B. (2008). How to Give Effective Feedback to Your Students. Alexandria: ASCD.

Tomanek, \& Olsson, F. (2009). A Web Survey on the Use of Active Learning to Support Annotationof Text Data. Proceedings of the NAACL HLT Workshop on Active Learning for Natural Language Processing (pp. 45-48). ACL Press.

Tomlinson, C. (2003). Differentiation in Practice. A Resource Guide for Differentiating Curriculum. Alexandria, VA: ASCD.

Walqui, A. (2006). Scaffolding Instruction for English Language Learners: A Conceptual Framework. International Journal of Bilingual Education and Bilingualism, 9(2), 159-180. http://dx.doi.org/10.1080/13670050608668639

Warford, M. K. (2011). The Zone of Proximal Teacher Development. Teaching and Teacher Education, 27, 252-258. http://dx.doi.org/10.1016/j.tate.2010.08.008

Watson, K., Modgil, C., \& Modgil, S. (Eds.). (1997). Educational Dilemmas: Debate and Diversity. London: Cassell.

West-Burnham, J. (1997). Managing Quality in Schools: Effective Strategies for Quality Based School Improvement (2nd ed.). London: Pitman. Retrieved from http://www.eghrmis.gov.my/docs/pdf

Yao, S. T., \& Raman, R. S. (2007). Problems and Challenges of Learning through a Second Language: The Case of Teaching of Science and Mathematics in English in the Malaysian Primary Schools. Kajian Malaysia, 25(2), 29-54.

Vygotsky, L. (1978). Mind in Society. Cambridge, MA: MIT Press.

\section{Copyrights}

Copyright for this article is retained by the author(s), with first publication rights granted to the journal.

This is an open-access article distributed under the terms and conditions of the Creative Commons Attribution license (http://creativecommons.org/licenses/by/3.0/). 